\title{
Diversity and Diffusion of Theories, Models, and Theoretical Constructs in eGovernment Research
}

\author{
Nripendra P. Rana ${ }^{1}$, Michael D. Williams ${ }^{1}$, Yogesh K. Dwivedi ${ }^{1}$, and Janet Williams ${ }^{2}$ \\ ${ }^{1}$ School of Business \& Economics, Swansea University, Swansea, SA2 8PP, United Kingdom \\ \{nrananp@gmail.com,M.D.Williams@swansea.ac.uk, \\ ykdwivedi@gmail.com\} \\ ${ }^{2}$ Faculty of Business and Society, University of Glamorgan, CF37 1DL, United Kingdom \\ jwillia3@glam.ac.uk
}

\begin{abstract}
After more than a decade of research in the field of e-government, it is now timely and appropriate to reflect upon the overall developmental directions in the area. The purpose of this paper is to explore research progress to date by systematically analysing the existing body of knowledge on egovernment related issues. Usable data relating to e-government research currently available were collected from 434 research articles. Based on the investigation of the various studies, our findings reveal that survey was the most utilised research method, and the Technology Acceptance Model was the most utilised theory to explain research models. Although a large number of theories and theoretical constructs were borrowed from the reference disciplines, their exploitation by e-government researchers appears largely random in approach. The paper also presents limitations and further research directions.
\end{abstract}

Keywords: E-government, Theories, Models, Theoretical Constructs, Methodologies.

\section{Introduction}

E-government is defined as the use of internet to deliver services and information to citizens and businesses $[27,28,66]$. It has been argued that the electronic government research now transitioning to maturity phase and emerging as a multi- and crossdisciplinary research area [72]. Although governments have adopted e-government rapidly, it remains comparatively a new experience. Over the past few years, a small but emerging body of scholarly literature about e-government has begun to come into view [57]. After a few years of rapid growth in the field it would be appropriate to pause and reflect on the state of e-government research [23] by means of examining the scholarly literature that has been published in it to date [57]. Despite the potential significant impacts of e-government systems on the public administrations, organizations, individuals, and society, so far, only a few systematic and thorough studies have been undertaken on the subject [23, 36, 44, 57, 72]. Andersen and Henriksen [2] conducted an analysis of 110 peer-reviewed journal papers and found that the IS research themes dominates the e-government research body and that 
interdisciplinary research involving core public administration research along with IS research is yet to emerge [2]. Gronlund [23] analysed a large number of papers from $D E X A, H I C S S$, and ECEG conferences to conclude that the publications in the conferences need to address quality criteria such as rigor and relevance in order to develop eGov into a mature research field. Yildiz [91] randomly reviewed the limitations of the published eGov research. In line with previous studies, Scholl [72] analysed a sample of publications from e-government and public administration conferences and journals in order to describe the profile of the core researcher community. Although these studies provided the systematic reviews of research issues, topics and research community, none of them have explored a systematic use of theories, models and theoretical constructs.

A number of previous studies $[2,26,91]$ have previously argued that the majority of published research in this area are weak in methodological and theoretical rigour and sometime less relevant to the practice. However, these arguments are yet to be supported by observation from the analysis of existing literature. Given the importance, complexity and existing gap in the topic area, and the lack of the published comprehensive review of the e-government adoption literature [81], the aim of this paper is to present a comprehensive retrospections of the previous egovernment research studies that have taken place in terms of diversity and diffusion of theories, models, and methodologies utilised to examine issues related to egovernment adoption and diffusion in both from individual and organizational perspectives.

\section{Methodology}

As a part of active research in the literature review, we began to search the articles related to e-government by developing some relevant set of keywords appropriately through our online journal database ISI Web of Knowledge ${ }^{\circledR}$. We finally found 823 articles from journals (such as Government Information Quarterly, Journal of Strategic Information Systems as some of the leading journals) and conferences (such as IFIP EGOV and Pacific Asia Conference of Information System as some of the leading conferences) on electronic government by the applied search process. With an extensive search process, we were able to find out 433 suitable journal and conference articles. Moreover, the dedicated journals for electronic government research were also considered for getting some appropriate articles required for our research. Three dedicated journals such as Transforming Government: People, Process, and Policy (TGPPP), Electronic Government, an International Journal (EGIJ), and International Journal of Electronic Government Research (IJEGR) were explored for the same. We found a total of 85 articles in TGPPP, 171 in EGIJ, and 90 in IJEGR. Out of these dedicated journal articles, 26 articles from $T G P P P, 91$ from $E G I J$, and 83 from $I J E G R$ were found relevant for electronic government research.

Considering all generic and specific electronic government literatures, it was found that a total of 434 research studies consisting of the articles from ISI Web of Knowledge ${ }^{\circledR}$ and dedicated journals were suitable for our studies. These usable articles were again scanned for those which have utilised certain theories, variables 
and constructs to analyse the various electronic government applications of different countries. The focus was also for those articles which have used the existing theories, models, and frameworks to discuss the e-government developments and issues. It was visualized that a total of 112 articles used the different theoretical constructs to discuss the overall e-government scenarios. It was also noticed that 70 studies used various theories, models, or frameworks either in their original structure or in the altered form to base their research models.

We collected overall 363 independent and 158 dependent variables from the studies which used variables and constructs to represent their research. After further scanning of these variables 177 independent and 110 dependent variables were subjected to further analysis. These independent and dependent variables were then categorized into four different groups such as environmental, individual, innovation, and organizational characteristics [39].

\section{Findings}

Table 1 shows the list of those theories or models which have been used either in its partial or complete form to represent the specific e-government research model along with the corresponding methodologies utilised for those studies. In course of screening all the research studies it was found that 70 of them used the existing models or theories to represent their cases. Analysing such models it was also noticed that TAM was the highly utilized model ( 25 studies) for examining the issues related with electronic government adoption. This is followed by Information System Success Model (11 studies) [14][15], diffusion of innovation (DOI) (11 studies), unified theory of acceptance and use of technology (UTAUT) [85] (9 studies), theory of planned behavior (TPB) (8 studies), extended technology acceptance model (TAM2) (4 studies), theory of reasoned action (TRA), structuration theory, and trust model (3 studies each) as some of the frequently utilised models and theories for representing the electronic government research models. While analysing the 70 research studies, it was also marked that $90 \%(\mathrm{~N}=63)$ of research studies based on any one of 29 existing research models or theories were published in or after the year 2006 whereas only $10 \%$ ( $N=7$ ) got published on or before the year 2005 . As far as the methodologies for these theories and models are concerned, most of them used survey $(\mathrm{N}=61)$ as their methodology whereas a very few theories $(\mathrm{N}=9)$ have used the other methodologies such as secondary data analysis, case studies, descriptive approach, and literature review and synthesis to represent their cases. Out of total 29 theories and models being employed to represent the models of 70 studies, two theories were used purely for case studies (Governance Theory, and Intermediation Theory), whereas three of them used only for descriptive approaches (Grounded Theory, Dynamic Info-Inclusion Theory, and Complexity Theory).

Moreover, out of 70 studies which used existing theories and models as the foundation for explaining their research models or frameworks, 20 used more than one theory or model. Five studies [20, 24, 29, 52, 58] used TAM and TPB together, four of them $[6,24,48,77]$ used even three theories or models, whereas three $[32,68$, 74] used TAM and DeLone and McLean's [15] IS success model together to propose 
Table 1. Model-wise utilised methodologies

\begin{tabular}{|c|c|}
\hline 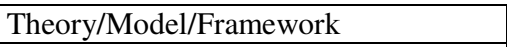 & \\
\hline Technology Acceptance Mode (TAM) & $\begin{array}{l}\text { Survey: [6], [8], [9], [12], [16], [20], [24], [29], } \\
\text { [32], [48], [49], [52], [58], [63], [67], [68], [74], } \\
\text { [77], [76], [79], [86]; Interview: [84], [86], [89]; } \\
\text { Secondary Data Analysis: [31]; Case Study: [69] }\end{array}$ \\
\hline $\begin{array}{l}\text { Information System Success Model } \\
\text { (DeLone and McLean, 1992, 2003) }\end{array}$ & $\begin{array}{l}\text { Survey: [19], [22], [30], [32], [55], [59], [65], [68], } \\
{[74],[80],[87]}\end{array}$ \\
\hline $\begin{array}{l}\text { Diffusion of Innovation/ Diffusion } \\
\text { Theory/ Innovation Diffusion Theory }\end{array}$ & $\begin{array}{l}\text { Survey: [6], [10], [16], [17], [24], [48], [58], [70], } \\
\text { [77], [82]; Case Study: [69] }\end{array}$ \\
\hline $\begin{array}{l}\text { Unified Theory of Acceptance and } \\
\text { Use of Technology (UTAUT) }\end{array}$ & $\begin{array}{l}\text { Survey: [7], [35], [51], [67], [71], [83], [88], [90]; } \\
\text { Theoretical Approach: [5] }\end{array}$ \\
\hline of Planned Behavior & ]$,[20],[24],[29],[33],[34],[41],[52]$ \\
\hline Exte & ], [69], [70]; Int \\
\hline Theo & [79] \\
\hline Trust & : [4] [6], [50], [60]; Questionnaire: [48] \\
\hline $\begin{array}{l}\text { Active Agent Framework based on } \\
\text { Structuration Theory }\end{array}$ & $\begin{array}{l}\text { Interview: [61], [75]; Literature Review: [62]; } \\
\text { Case Study: [75] }\end{array}$ \\
\hline \multicolumn{2}{|c|}{$\begin{array}{l}\text { Other less frequently utilized theory: Decomposed Theory of Planned Behavior-Survey: } \\
\text { [46], [47]; IS Success Model [60]- Survey [78]; Resident Decision Model- Questionnaire: } \\
\text { [25]; IS Planning and Investment Model- Secondary Dataset, Survey, Interviews: [45]; } \\
\text { Social Cognitive Theory: Questionnaire Survey: [51]; Leadership Theory- Case Study, } \\
\text { Interviews; Stakeholder Theory- Case Study, Interviews: [53]; Actor Network Theory- Case } \\
\text { Study, Survey: [3]; Schutzian Theory of Human Agency- Descriptive Approach: [21]; } \\
\text { Dynamic Info-Inclusion Model- Secondary Data Analysis: [40]; Theory of Connection- } \\
\text { Literature Study: [13]; Grounded Theory- Secondary Data Analysis: [31]; Governance } \\
\text { Theory- Case Study: [43]; Structurational Model of Technology- Literature Review: [62]; } \\
\text { Transaction Cost Analysis- Survey, Questionnaire: [77]; Coordination Theory- Case Study, } \\
\text { Interviews: [38]; Institutional Theory- Web-Based Survey: [54]; Complexity Theory- } \\
\text { Descriptive Approach: [18]; Intermediation Theory- Case Studies: [37]; IS Success Sub- } \\
\text { Model- Survey: [19] }\end{array}$} \\
\hline
\end{tabular}

and test their research models. One study [79] used TAM and TRA together however, other few studies have used two similar models to explain the resulting research, such as Sang et al. [69] used TAM and TAM2, Floropoulos et al. [19] used two success models: DeLone and McLean's [14] updated IS success model, and Seddon's [73] IS success sub-model, and Parvez [62] based his model on Gidden's structuration theory, and Orlikowski's structurational model of technology (SMT).

Table 2 demonstrates a few variables from a list of 177 unique independent variables selected from an overall count of 363 variables used across 112 studies. These unique independent variables are categorized into four different groups such as environmental (23 variables), organizational (91 variables), individual (35 variables), and innovation (28 variables) characteristics as per their traits. Environmental, organizational, individual, and innovation characteristics are the factors that describe the environment, organization, individual, and innovational traits [39] of the underlying variables in the suitable contexts respectively. It was found that organizational characteristics were the most utilised one among the others followed by individual, innovative, and environmental. Amongst four categories, largest $(\mathrm{C}=11)$ number of variables among organizational characteristics category were used as independent as well as dependent 
variables. Similarly, six variables from innovation characteristics, five from individual characteristics, and one from environmental characteristics were used both as independent as well as dependent variables. Analysing all 112 studies that used the theoretical constructs, it was found that only 12 of them were related to pure organizational perspectives.

Table 2. Independent variables and their final four groupings (Adapted from Jeyaraj et al. [39])

\begin{tabular}{|c|c|}
\hline Categories & Example Independent Variables $^{* * *}$ \\
\hline $\begin{array}{l}\text { Environmental Characteristics } \\
\text { The factors that describe the } \\
\text { environment }\end{array}$ & $\begin{array}{l}\text { Adequacy, Competition, Dominance, E-Commerce, } \\
\text { External Influence, Linguistic Diversity, Persuasion, } \\
\text { Primary Influence, Social Norms, Web Adoption* }\end{array}$ \\
\hline $\begin{array}{l}\text { Organizational Characteristics } \\
\text { The factors that describe an } \\
\text { organization }\end{array}$ & $\begin{array}{l}\text { Administrative Autonomy, Business Competitiveness*, } \\
\text { Business, Internet Use, Centralization, Clarity, } \\
\text { Collaboration, Cost, Experience, Employee, Enacted } \\
\text { Technology*, Facilitating Conditions, IT Leadership*, } \\
\text { Job Productivity }\end{array}$ \\
\hline $\begin{array}{l}\text { Individual Characteristics } \\
\text { The factors that describe an } \\
\text { individual }\end{array}$ & $\begin{array}{l}\text { Age, Anxiety, Attitude*, Behavioral Intention*, } \\
\text { Commitment*, Education, Effort Expectancy, } \\
\text { Empathy, Gender, Image, Income, Individual Impact*, } \\
\text { Perceived Behavioral Control*, Self-Efficacy, Usage }\end{array}$ \\
\hline $\begin{array}{l}\text { Innovation Characteristics } \\
\text { The factors that describe the } \\
\text { innovation }\end{array}$ & $\begin{array}{l}\text { Accessibility, Accuracy, Compatibility, Complexity, } \\
\text { Cumbersome, Perceived Ease of Use*, Perceived } \\
\text { Knowledge, Perceived Quality, Perceived Usefulness*, } \\
\text { Relative Advantage, Self-actualization, Service } \\
\text { Quality*, System Quality*, }\end{array}$ \\
\hline
\end{tabular}

[Legend *: Variables also used as dependent variables; **: Only a few example independent variables shown due to space constraints]

Similar to the independent variables categorization, a list of 110 unique dependent variables gathered from a collection of overall 177 dependent variables from 112 research studies. These variables were also divided into four categories: environmental (11 variables), organizational (52 variables), individual (25), and innovation (22 variables). The most frequently used dependent variables include intention to use (23 studies), perceived usefulness (20 studies), behavioral intention (16 studies), adoption behavior (13 studies each), and trust ( 8 studies). This trend is similar to the one investigated in a study of IT innovation and adoption research carried out by Jeyaraj et al. [39]. The categorization also revealed ethnic minority, business competitiveness, environmental activism, and e-elections as the environmental characteristics; competitive advantage, net benefits, customer, decision quality, revenue generation, results, and social trust as the organizational characteristics; age, attitude, behavioral intention, satisfaction, and usage as individual characteristics; and efficiency, information quality, service quality, system quality, enacted technology, and perceived usefulness as innovation characteristics to count a few. Due to the space limitation all variables are not listed in Table 2, but interested readers may request them from the authors. 


\section{Discussion}

Looking at the theories and models along with the methodologies applied for 70 studies which used the existing models and theories either in original or altered forms to represent the e-government research models, it was found that survey was the most frequently utilized method across various theories and models explored. The striking reason for this may be because of the ease of collecting data based on the existing models would have inspired the researcher to go for survey methodology. The compelling reason for using any other methodologies except survey such as case study, descriptive approach, and secondary data analysis, literature study etc. may be completely based on the qualitative nature of the theories such as governance theory, intermediation theory, grounded theory, dynamic info-inclusion model, theory of connection, and complexity theory applied to represent the suitable research cases.

Investigating the theories and models used by the studies to include different constructs, it was seen that few studies used even three theories or models to propose an integrated model. For example, a study by Carter and Belanger [6] integrated the combination of three models to propose and test their conceptual model. The theoretical models, in particular TAM and DOI, have overlapping constructs. The 'complexity' construct from DOI is similar to the perceived ease of use (PEOU) construct from TAM. Similarly, some researchers have suggested that perceived usefulness and relative advantage are the similar constructs [6]. Carter and Belanger [6] argued that they included both DOI and TAM in the e-government adoption because DOI adds up significant contribution to the prophecy of adoption intent [64]. But, combining similar constructs together definitely raises the issue of repeating the similar variables and would make the resulting model less relevant and more repetitive in nature that may likely to add minimal contribution to the existing knowledge. Similarly, Floropoulos et al. [19] adapted both DeLone and McLean [15] updated IS success model, and Seddon's [73] IS success sub-model. This raises a serious question of repetition of constructs as the former model is constituted of the later model.

Examining the unique independent constructs from 112 studies indicated that more than $50 \%$ of variables fall under the organizational characteristics even though only 12 out of 112 studies have investigated organizational issues. The major reason for such diverse extent of use of organizational characteristics might be due to certain variables which were although used for employees (considered as individuals), can be more influential to describe the organizational traits than the individual or personal characteristics. The investigation of 10 or higher frequencies for some of the constructs such as perceived ease of use (29 studies), perceived usefulness (24 studies), education (17 studies), age (15 studies), trust (14 studies), gender (13 studies), compatibility (12 studies), subjective norm (12 studies), attitude (11 studies), and self-efficacy (10 studies each) clearly designated that the individual and technology/innovation traits are more frequently examined in the e-government adoption and diffusion research than the organizational characteristics. However, a majority of constructs with organizational characteristics have fewer occurrences across the varied research studies. 


\section{Conclusions}

The following prominent points can be drawn from findings and discussions of the study:

(1) Technology Acceptance Model (TAM) was the highly recommended model (25 studies) for representing e-government research studies. This is followed by DeLone and McLean's IS Success Model ( $\mathrm{N}=11)$, Diffusion of Innovation $(\mathrm{N}=11)$, Unified Theory of Access and Use of Technology (UTAUT) (N=9), and Theory of Planned Behavior (TPB) $(\mathrm{N}=8)$ as some of the most frequently utilised models.

(2) $90 \%(\mathrm{~N}=63)$ of overall research studies $(\mathrm{N}=70)$ which are based on any one of 29 existing research models or theories were published in the span of last five years only.

(3) TAM and TAM2 have been used together in some studies even though TAM2 model is the extension of TAM model.

(4) The survey method was used in $87 \%(\mathrm{~N}=61)$ of the total number of studies $(\mathrm{N}=70)$.

(5) Although only 12 studies were related to pure organizational perspective, $51 \%(\mathrm{~N}=91)$ of total independent constructs $(\mathrm{N}=177)$, and $47 \%(\mathrm{~N}=52)$ of total dependent constructs $(\mathrm{N}=110)$ fell under organizational characteristics category.

(6) From a list of variables, 23 (i.e. 11 from organizational, 6 from innovation, 5 from individual, 1 from environmental) constructs were used both as independent as well as dependent variable.

(7) Perceived usefulness, attitude, satisfaction, perceived ease of use, and perceived behavioral control were some of the most frequently utilised independent as well as dependent variables.

\section{Limitations and Future Research Directions}

The first limitation of this research is the inaccessibility of a number of relevant studies through researchers' library. The accessibility of such papers would have helped in performing more accurate and in depth analysis. Secondly, this study does not take into consideration the moderating variables. Thirdly, this study concentrates only on the specific aspects of adoption and diffusion for e-government research. Finally, the papers from conferences such as DEXA, HICSS, and ECEG and journal such as Information Polity have not been explored to identify relevant research studies on e-government adoption and diffusion.

These limitations of the existing study can be proved to be a step forward toward the future research directions. More papers which could not be accessed should be taken into consideration in the future review of e-government research. The consideration of moderating variables and their explanation may bring in some more interesting facts to correlate and explore along with independent and dependent 
variables. Also, this study only explored and analysed theories and models related to adoption and diffusion of e-government. However, there might be a number other theories and models (for example, Klievink and Janssen [42] examined e-government transformation and evolution using Nolan's stage model) that have used to study other aspects of e-government. Therefore, a further effort is required to explore and identify such theories and relevance in e-government context.

\section{References}

1. Al-Shafi, S., Weerakkody, V.: Implementing Free Wi-Fi in Public Parks: An Empirical Study in Qatar. International Journal of Electronic Government Research 5(3), 21-35 (2009)

2. Andersen, K.V., Henriksen, H.Z.: The First Leg of E-Government Research: Domains and Application Areas 1998-2003. International Journal of Electronic Government Research 1(4), 26-44 (2005)

3. Azad, B., Faraj, S.: E-Government institutionalizing practices of a land registration mapping system. Government Information Quarterly 26(1), 5-14 (2009)

4. Belanger, F., Carter, L.: Trust and risk in e-government adoption. Journal of Strategic Information Systems 17(2), 165-176 (2008)

5. Belanger, F., Carter, L.D.: U-government: a framework for the evolution of e-government. Electronic Government, an International Journal 2(4), 426-445 (2005)

6. Carter, L., Belanger, F.: The utilization of e-government services: citizen trust, innovation and acceptance factors. Information Systems Journal 15(1), 5-25 (2005)

7. Carter, L., Schaupp, L.C.: Relating Acceptance and Optimism to E-File Adoption. International Journal of Electronic Government Research 5(3), 62-74 (2009)

8. Carter, L.: E-government diffusion: a comparison of adoption constructs. Transforming Government: People, Process, and Policy 2(3), 147-161 (2008)

9. Chiang, L.: Trust and security in the e-voting system. Electronic Government, an International Journal 6(4), 343-360 (2009)

10. Choudrie, J., Brinkman, W., Pathania, R.: Using diffusion theory to determine the digital divide in e-services: two UK local-area perspectives. Electronic Government, an International Journal 4(3), 345-359 (2007)

11. Chu, P.Y., Hsiao, N., Lee, F.W., Chen, C.W.: Exploring success factors for Taiwan's government electronic tendering system: behavioral perspectives from end users. Government Information Quarterly 21(2), 219-234 (2004)

12. Colesca, S.E., Dobrica, L.: Adoption and use of e-government services: The case of Romania. Journal of Applied Research and Technology 6(3), 204-217 (2008)

13. Davidrajuh, R.: Planning e-government start-up: a case study on e-Sri Lanka. Electronic Government, an International Journal 1(1), 92-106 (2004)

14. DeLone, W.H., McLean, E.R.: Information systems success: The quest for the dependent variable. Information Systems Research 3(1), 60-95 (1992)

15. DeLone, W.H., McLean, E.R.: The DeLone and McLean Model of information systems success: A ten year update. Journal of Management Information Systems 19(4), 9-30 (2003)

16. Dimitrova, D.V., Chen, Y.C.: Profiling the adopters of e-government information and services - The influence of psychological characteristics, civic mindedness, and information channels. Social Science Computer Review 24(2), 172-188 (2006) 
17. Dwivedi, Y.K., Williams, M.D.: Demographic Influence on UK citizen's e-government adoption. Electronic Government, an International Journal 5(3), 261-274 (2008)

18. Falivene, G.M., Silva, G.M.: Reflections and Proposals on Public Officials Training and Promotion of e-Government. International Journal of Electronic Government Research 4(2), 43-58 (2008)

19. Floropoulos, J., Spathis, C., Halvatzis, D., Tsipouridou, M.: Measuring the success of the Greek Taxation Information System. International Journal of Information Management 30(1), 47-56 (2010)

20. Fu, J.R., Farn, C.K., Chao, W.P.: Acceptance of electronic tax filing: A study of taxpayer intentions. Information \& Management 43(1), 109-126 (2006)

21. Fu-Lai, Y.T.: Uncertainty, human agency and e-government. Transforming Government: People, Process, and Policy 2(4), 283-296 (2008)

22. Gotoh, R.: Critical factors increasing user satisfaction with e-government services. Electronic Government, an International Journal 6(3), 252-264 (2009)

23. Gronlund, A.: State of the art in e-government research: surveying conference publications. International Journal of Electronic Government Research 1(4), 1-25 (2005)

24. Gumussoy, C.A., Calisir, F.: Understanding factors affecting e-reverse auction use: An integrative approach. Computers in Human Behavior 25(4), 975-988 (2009)

25. Hamner, M., Al-Qahtani, F.: Enhancing the case for Electronic Government in developing nations: A people-centric study focused in Saudi Arabia. Government Information Quarterly 26(1), 137-143 (2009)

26. Heeks, R., Bailure, S.: Analysing e-government research: Perspectives, philosophies, theories, methods, and practice. Government Information Quarterly 24, 243-265 (2007)

27. Ho, A.T.K., Ni, A.Y.: Explaining the adoption of e-government features: A case study of Iowa County treasurers' offices. American Review of Public Administration 34(2), 164180 (2004)

28. Holden, S.H., Norris, D.F., Fletcher, P.D.: Electronic government at the local level: Progress to date and future issues. Public Performance \& Management Review 26(4), 325$344(2003)$

29. Horst, M., Kuttschreuter, M., Gutteling, J.M.: Perceived usefulness, personal experiences, risk perception and trust as determinants of adoption of e-government services in The Netherlands. Computers in Human Behavior 23(4), 1838-1852 (2007)

30. Hsu, F.M., Chen, T.Y.: Understanding Information Systems Usage Behavior in EGovernment: The Role of Context and Perceived Value. In: Pacific Asia Conference on Information Systems (2007)

31. Hsu, L.: The adoption and implementation of Projects-ABCDE (MOEA) - based on Grounded and TAM theory. Electronic Government, an International Journal 2(2), 144-159 (2005)

32. Hu, P.J.H., Brown, S.A., Thong, J.Y.L., Chan, F.K.Y., Tam, K.Y.: Determinants of Service Quality and Continuance Intention of Online Services: The Case of eTax. Journal of the American Society for Information Science and Technology 60(2), 292-306 (2009)

33. Hung, S.Y., Chang, C.M., Yu, T.J.: Determinants of user acceptance of the e-Government services: The case of online tax filing and payment system. Government Information Quarterly 23(1), 97-122 (2006)

34. Hung, S.Y., Tang, K.Z., Chang, C.M., Ke, C.D.: User acceptance of intergovernmental services: An example of electronic document management system. Government Information Quarterly 26(2), 387-397 (2009)

35. Hung, Y.H., Wang, Y.S., Chou, S.C.T.: User Acceptance of E-Government Services. In: Pacific Asia Conference on Information Systems (2007) 
36. Jaeger, P.T.: The endless wire: Egovernment as global phenomenon. Government Information Quarterly 20, 323-331 (2003)

37. Janssen, M., Klievink, B.: The Role of Intermediaries in Multi-Channel Service Delivery Strategies. International Journal of Electronic Government Research 5(3), 36-46 (2009)

38. Janssen, M., Kuk, G.: E-Government business Models for Public service networks. International Journal of Electronic Government Research 3(3), 54-71 (2007)

39. Jeyaraj, A., Rottman, J.W., Lacity, M.C.: A review of the predictors, linkages, and biases in IT innovation adoption research. Journal of Information Technology 21, 1-23 (2006)

40. Joia, L.A.: Bridging the digital divide: some initiatives in Brazil. Electronic Government, an International Journal 1(3), 300-315 (2004)

41. Kanat, I.E., Ozkan, S.: Exploring citizens' perception of government to citizen services: a model based on theory of planned behaviour (TPB). Transforming Government: People, Process, and Policy 3(4), 406-419 (2009)

42. Klievink, B., Janssen, M.: Realizing joined-up government - Dynamic capabilities and stage models for transformation. Government Information Quarterly 26, 275-284 (2009)

43. Kolsaker, A.: Reconceptualising e-government as a tool of governance: the UK case. Electronic Government, an International Journal 3(4), 347-355 (2006)

44. Kraemer, K.L., King, J.L.: Information technology and administrative reform: Will the time after e-government be different? (2003), retrieved from http: / /www. crito.uci.edu

45. Krell, K., Matook, S.: Competitive advantage from mandatory investments: An empirical study of Australian firms. Journal of Strategic Information Systems 18(1), 31-45 (2009)

46. Lau, A.S.M., Kwok, V.W.S.: How e-government strategies influence e-commerce adoption by SMEs. Electronic Government, an International Journal 4(1), 20-42 (2007)

47. Lau, A.S.M.: Strategies to encourage the adoption of G2C e-government services in Hong Kong. Electronic Government, an International Journal 1(3), 273-292 (2004)

48. Lean, O.K., Zailani, S., Ramayah, T., Fernando, Y.: Factors influencing intention to use egovernment services among citizens in Malaysia. International Journal of Information Management 29(6), 458-475 (2009)

49. Lee, J., Rao, H.R.: Task complexity and different decision criteria for online service acceptance: A comparison of two e-government compliance service domains. Decision Support Systems 47(4), 424-435 (2009)

50. Li, X., Hess, T.J., Valacich, J.S.: Why do we trust new technology? A study of initial trust formation with organizational information systems. Journal of Strategic Information Systems 17(1), 39-71 (2008)

51. Loo, W.H., Yeow, P.H.P., Chong, S.C.: User acceptance of Malaysian government multipurpose smartcard applications. Government Information Quarterly 26(2), 358-367 (2009)

52. Lu, C.T., Huang, S.Y., Lo, P.Y.: An empirical study of on-line tax filing acceptance model: Integrating TAM and TPB. African Journal of Business Management 4(5), 800-810 (2010)

53. Luk, S.C.Y.: The impact of leadership and stakeholders on the success/failure of egovernment service: Using the case study of e-stamping service in Hong Kong. Government Information Quarterly 26(4), 594-604 (2009)

54. Luna-Reyes, L.F., Gil-Garcia, J.R., Estrada-Marroquin, M.: The impact of institutions on inter organizational IT projects in the Mexican federal government. International Journal of Electronic Government Research 4(2), 27-42 (2008)

55. Mirchandani, D.A., Johnson, J.H., Joshi, K.: Perspectives of citizens towards e-government in Thailand and Indonesia: A multigroup analysis. Information Systems Frontiers 10(4), 483-497 (2008) 
56. Myers, B.L., Kappelman, L.A., Prybutok, V.R.: A comprehensive model for assessing quality and productivity of the information systems function: toward a theory for information systems assessment. Information Resources Management Journal, 6-25 (1997)

57. Norris, D.F., Lloyd, B.A.: The Scholarly Literature on e-Government: Characterizing a nascent Field. International Journal of Electronic Government Research 2(4), 40-56 (2006)

58. Ojha, A., Sahu, G.P., Gupta, M.P.: Antecedents of paperless income tax filing by young professionals in India: an exploratory study. Transforming Government: People, Process, and Policy 3(1), 65-90 (2009)

59. Ozkan, S., Koseler, R., Baykal, N.: Evaluating learning management systems: adoption of hexagonal e-learning assessment model in higher education. Transforming Government: People, Process, and Policy 3(2), 111-130 (2009)

60. Parent, M., Vandebeek, C.A., Gemino, A.C.: Building citizen trust through e-government. Government Information Quarterly 22(4), 720-736 (2009)

61. Parvez, Z.: E-Democracy from the Perspective of Local Elected Members. International Journal of Electronic Government Research 4(3), 20-35 (2008)

62. Parvez, Z.: Examining e-democracy through a double structuration loop. Electronic Government, an International Journal 3(3), 329-346 (2006)

63. Phang, C.W., Sutanto, J., Kankanhalli, A., Li, Y., Tan, B.C.Y., Teo, H.H.: Senior citizens' acceptance of information systems: A study in the context of e-government services. IEEE Transactions on Engineering Management 53(4), 555-569 (2006)

64. Plouffe, C., Hulland, J., Vandenbosch, M.: Research report: richness versus parsimony in modeling technology adoption decisions - understanding merchant adoption of a smart card-based payment system. Information Systems Research 12, 208-222 (2001)

65. Prybutok, V.R., Zhang, X.N., Ryan, S.D.: Evaluating leadership, IT quality, and net benefits in an e-government environment. Information and Management 45(3), 143-152 (2008)

66. Reddick, C.G.: A two-stage model of e-government growth: Theories and empirical evidence for U.S. cities. Government Information Quarterly 21(1), 51-64 (2004)

67. Sahu, G.P., Gupta, M.P.: Users' Acceptance of E-Government: A study of Indian central Excise. International Journal of Electronic Government Research 3(3), 1-21 (2007)

68. Sambasivan, M., Wemyss, G.P., Rose, R.C.: User acceptance of a G2B system: a case of electronic procurement system in Malaysia. Internet Research 20(2), 169-187 (2010)

69. Sang, S., Lee, J.D., Lee, J.: E-government adoption in ASEAN: the case of Cambodia. Internet Research 19(5), 517-534 (2009)

70. Sang, S., Lee, J.D., Lee, J.: E-government adoption in Cambodia: a partial least squares approach. Transforming Government: People, Process, and Policy 4(2), 138-157 (2010)

71. Schaupp, L.C., Carter, L., McBride, M.E.: E-file adoption: A study of US taxpayers' intentions. Computers in Human Behavior 26(4), 636-644 (2010)

72. Scholl, H.J(J.): Profiling the EG Research Community and Its Core. In: Wimmer, M.A., Scholl, H.J., Janssen, M., Traunmüller, R. (eds.) EGOV 2009. LNCS, vol. 5693, pp. 1-12. Springer, Heidelberg (2009)

73. Seddon, P.B.: A respecification and extension of the DeLone and McLean model of IS success. Information Systems Research 8(3), 240-253 (1997)

74. Segovia, R.H., Jennex, M.E., Beatty, J.: Paralingual Web Design and Trust in EGovernment. International Journal of Electronic Government Research 5(1), 36-49 (2009)

75. Senyucel, Z.: Assessing the impact of e-government on providers and users of the IS function: a structuration perspective. Transforming Government: People, Process, and Policy 1(2), 131-144 (2007) 
76. Seyal, A.H., Pijpers, G.G.M.: Senior government executives' use of the internet: A Bruneian scenario. Behaviour and Information Technology 23(3), 197-210 (2004)

77. Shareef, M.A., Kumar, U., Kumar, V., Dwivedi, Y.K.: Identifying critical factors for adoption of e-government. Electronic Government, an International Journal 6(1), 70-96 (2009)

78. Sun, S., Ju, T.L., Chen, P.: E-government impacts on effectiveness: a survey study of an eofficial-document system. Electronic Government, an International Journal 3(2), 174-189 (2006)

79. Tang, H., Chung, S.H., Se, C.W.: Examining the impact of possible antecedents on service usage: an empirical study on Macao e-government. Electronic Government, an International Journal 6(1), 97-109 (2009)

80. Teo, T.S.H., Srivastava, S.C., Jiang, L.: Trust and Electronic Government Success: An Empirical Study. Journal of Management Information Systems 25(3), 99-131 (2008)

81. Titah, R., Barki, H.: E-government adoption and acceptance: A literature review. International Journal of Electronic Government Research 2(3), 23-57 (2006)

82. Tung, L.L., Rieck, O.: Adoption of electronic government services among business organizations in Singapore. Journal of Strategic Information Systems 14(4), 417-440 (2005)

83. van Dijk, J.A.G.M., Peters, O., Ebbers, W.: Explaining the acceptance and use of government Internet services: A multivariate analysis of 2006 survey data in the Netherlands. Government Information Quarterly 25, 379-399 (2008)

84. Vathanophas, V., Krittayaphongphun, N., Klomsiri, C.: Technology acceptance toward egovernment initiative in Royal Thai Navy. Transforming Government: People, Process, and Policy 2(4), 256-282 (2008)

85. Venkatesh, V., Morris, M.G., Davis, G.B., Davis, F.D.: User acceptance of information technology: Toward a unified view. MIS Quarterly 27(3), 425-478 (2003)

86. Vonk, G., Geertman, S., Schot, P.: New technologies stuck in old hierarchies: The diffusion of geo-information technologies in Dutch public organizations. Public Administration Review 67(4), 745-756 (2007)

87. Wang, Y.S., Liao, Y.W.: Assessing eGovernment systems success: A validation of the DeLone and McLean model of information systems success. Government Information Quarterly 25(4), 717-733 (2008)

88. Wang, Y.S., Shih, Y.W.: Why do people use information kiosks? A validation of the Unified Theory of Acceptance and Use of Technology. Government Information Quarterly 26(1), 158-165 (2009)

89. Wang, Y.S.: The adoption of electronic tax filing systems: an empirical study. Government Information Quarterly 20(4), 333-352 (2002)

90. Yeow, P.H.P., Loo, W.H.: Acceptability of ATM and Transit Applications Embedded in Multipurpose Smart Identity Card: An Exploratory Study in Malaysia. International Journal of Electronic Government Research 5(2), 37-56 (2009)

91. Yildiz, M.: E-Government research: reviewing the literature, limitations, and ways forward. Government Information Quarterly 24, 646-665 (2007) 